\title{
A New Insight into Pruning Strategy in the Biennial Cycle of Fruiting: Vegetative Growth at Shoot and Whole-tree Level, Yield and Fruit Quality of Apple
}

\author{
Ersin ATAY \\ TAGEM Fruit Research Institute, 32500, Egirdir, Isparta, Turkey; ersin.atay@tarim.gov.tr
}

\begin{abstract}
Knowledge of the growth dynamics of young and mature trees contributes to development of efficient orchard management practices. In this experiment, the aim was to provide apple growers with practical information on how vegetative growth (at both shoot and whole-tree level), yield and fruit quality change during the transition period, from young to mature trees. The experiment orchard was planted at $3.5 \mathrm{~m} \times 1 \mathrm{~m}$ inter-row and intra-row spacings, respectively, with 'Golden Delicious'/M.9 trees. Trees were trained since planting as modified vertical axis. Vegetative growth at shoot level reacted differently to yield load than that at the whole-tree level. The yield, yield efficiency and annual canopy volume increase and decrease (a vegetative growth indicator at the whole-tree level) showed a positive correlation with shoot length. TCSA (annual increase and actual TCSA), as another vegetative growth indicator at whole-tree level in the experiment, correlated negatively with shoot length. The yield varied biennially and, was greatest in the seventh year after planting $\left(21.76 \pm 8.46 \mathrm{~kg}\right.$ tree $e^{-1}$, corresponding to an orchard yield of $\sim 62 \mathrm{t} \mathrm{ha}^{-1}$ ) that is an acceptable tonnage in the region of the experiment. To maintain the balance between vegetative growth and fruiting, orchard management practices should be conducted considering yield. No pruning or light pruning is recommended in the 'off-year' of biennial cycle of fruiting as a result of this study.
\end{abstract}

Keywords: Malus $\times$ domestica, irregular bearing, minimal pruning, non-plastic cultivars, plastic cultivars

\section{Introduction}

Considerable vegetative growth with minimal pruning is desirable to fill the allocated spaces of trees in the rows in the young orchards (Robinson, 2003). As trees age, a moderate or reduced vegetative growth is preferred (Atay and Lauri, 2013). Under a given set of conditions, fruit trees can show different vegetative growth reactions at shoot and whole-tree level (Lauri et al., 2010). The expectation from a bearing tree is to maintain regular yields of marketable fruit (Pellerin et al., 2012). However, getting a 'regular bearing' in a given orchard is not possible with all commercial apple cultivars due to intrinsic biennial bearing patterns, and fruit growers lack effective strategies to maintain regular bearing from year to year (Smith and Samach, 2013). Biennial bearing results from the balance between vegetative growth and fruiting, and how to optimize the two is one of the goals of modern fruit growing (Lauri and Lespinasse, 2000). The role of hormone/signals (e.g. gibberellin, auxin and abscisic acid) originating from developing fruit seems the main reason for this biennial cycle of fruiting in many fruit species (Chan and Cain, 1967; Monselise and Goldschmidt, 1982; Smith and Samach, 2013), but the susceptibility to biennial bearing is highly dependent on the genotype (Atay et al., 2013). In contrast to the regular bearing cultivars (e.g. Pink Lady ${ }^{\mathrm{TM}}$ 'Rosy Glow' and 'Granny Smith'), the others (e.g. 'Golden Delicious' and 'Fuji') generally show an irregular bearing pattern with a low frequency of bourse-overbourse that is the one of the most important aspects of regular bearing in apple (Lauri et al., 1995). The regular bearing trait of 'plastic' cultivars (e.g. 'Golden Delicious' and 'Gala') can be improved by sophisticated pruning techniques such as artificial extinction (Lauri et al., 1995; Tustin et al., 2012), which is less efficient for 'non-plastic' cultivars (e.g. 'Fuji') (Lauri and Corelli-Grappadelli, 2014). The objective of this work was to provide apple growers with practical information on changes, during the transition period from young to mature trees, first on vegetative growth (at both shoot and whole-tree levels), second on yield, and third on fruit quality in an intensive apple orchard on a deep fertile soil containing an irregular bearing cultivar. Thus, the meaning of vegetative growth remains obscure for fruit growers, and existing knowledge does not provide fruit growers which pruning strategies that can avoid biennial bearing.

\section{Materials and Methods}

\section{Plant material}

The experiment was conducted at an experimental plot of Fruit Research Institute (MAREM; http://arastirma.tarim.gov. 
$\mathrm{tr} / \mathrm{marem})$, located in the West Mediterranean Region of Turkey. One-year-old unbranched nursery trees of "Golden Delicious' $/$ M.9 combination were planted on a clay-roam soil at $3.5 \mathrm{~m} \times 1 \mathrm{~m}$ inter-row and intra-row spacings, respectively, delivering an overall orchard tree density of $2857 \mathrm{ha}^{-1}$. Trees were supported by a $2.2 \mathrm{~m}$ trellis system and trained to a modified vertical axis system, in which renewal cuts were performed rather than shortening cuts. The orchard had drip irrigation with fertigation. 'Red Delicious' as pollinator cultivar was planted in the orchard. There were no pollination issues during the experiment and no blossom chemical thinning was applied. Hand-thinning following the physiological drop was managed according to local conditions to ensure commercial fruit quality.

\section{Data collection}

Data were collected over four subsequent years, from the fifth year to the eighth year after planting using the same trees. Trunk cross-sectional area (TCSA) and canopy volume measurements were started one year prior (i.e. in the fourth year following planting). Shoots length was measured in the seventh year and eighth year after planting.

Trunk diameter was measured by a digital caliper at $15 \mathrm{~cm}$ above the budding point, and converted into TCSA by the following formula:

TCSA $=\pi(\text { trunk diameter } / 2)^{2}$ (Zhao etal., 2016).

Canopy volume, assuming trees to be represented by prolate spheroid, was calculated by the equation:

Volume $=4 / 3 \pi a b^{2}$,

where $a=1 / 2$ canopy height from the lowest scaffold branch and $b=1 / 2$ canopy width (Westwood, 1993). The length of all shoots ending the scaffold branches was measured on four shoots per tree at breast height that were randomly chosen. The scaffold branches studied were kept with no heading cut back to old wood. Most of the shoots were in the bourse shoot category, i.e. they were generated from axils of spur leaves beneath the flower cluster, and have sympodial and sylleptic character (Costes and Guedon, 2002; Lauri et al., 2010). All measurements for vegetative growth (i.e. TCSA, canopy volume and shoot length) were performed in the dormant season before pruning.

Yield at harvest was calculated in terms of $\mathrm{t}$ per ha. Biennial bearing index (BBI) was calculated using the following formula (Hoblyn et al. 1936; Monselise and Goldschmidt, 1982):

$\mathrm{BBI}=1 /(\mathrm{n}-1) \times\left[\left|\left(\mathrm{a}_{2}-\mathrm{a}_{1}\right)\right| /\left(\mathrm{a}_{2}+\mathrm{a}_{1}\right)+\left|\left(\mathrm{a}_{3}-\mathrm{a}_{2}\right)\right| /\left(\mathrm{a}_{3}+\mathrm{a}_{2}\right) \ldots+\mid\right.$ $\left.\left(\mathrm{a}_{(\mathrm{n})}-\mathrm{a}_{(\mathrm{n}-1)}\right) \mid /\left(\mathrm{a}_{(\mathrm{n})}+\mathrm{a}_{(\mathrm{n}-1)}\right)\right]$,

where $n=$ the number of year and $a=$ yield in $\mathrm{kg} \mathrm{tree}^{-1}$.

BBI values are between ' 0 ' (no biennial bearing) and ' 1 ' (no yield in one of the years) (Pearce and Dobersek-Urbanc, 1967; Smith and Samach, 2013). Yield efficiency was computed as kg $\mathrm{cm}^{-2}$ TCSA (YETCSA), $\mathrm{kg} \mathrm{cm}^{-2}$ annual TCSA increase (YE $\mathrm{YCSAInc}_{\mathrm{T}}$ ), and $\mathrm{kg} \mathrm{m}^{-3}$ canopy volume increase (YEVo). Soluble solids content (SSC) of fruit juice was measured by a digital refractometer (HANNA, HI 96801, USA). Fruit flesh firmness $\left(\mathrm{kg} \mathrm{cm}^{-2}\right)$ was measured on two opposite sides of the fruit by a hand-held penetrometer (Model FT 011, Effegi, Italy) fitted with an 11.1 $\mathrm{mm}$ probe. For titratable acidity, $10 \mathrm{ml}$ of fruit juice were titrated with $0.1 \mathrm{M} \mathrm{NaOH}$ to $\mathrm{pH} 8.15$, using a digital buret (Isolab Digitrate, UK) and malic acid content was calculated (Atay et al., 2010). Fruit weight was measured by a digital scale sensitive to 0.01 g. Fruit skin colour, $b^{*}$ value here, was recorded by using a colorimeter (Minolta CR-400, Japan). The values of $\mathrm{b}^{*}$ can be positive ('+' = yellow) or negative ( $(-'=$ blue) (Alcobendas et al.,
2012). The $\mathrm{pH}$ of fruit was measured using a digital $\mathrm{pH}$ meter (HANNA, HI 2211, USA).

\section{Data analysis}

All variables were subjected to analysis of variance (ANOVA), consideringyear as the main factor. When the $F$-test statistics were significant, means were separated using Least Significant Difference (LSD) multiple comparison test. Correlation analyses were performed to investigate relationships among the variables studied. Data were analyzed using SAS-JMP software version 7.0 (http://www.jmp.com/software).

\section{Results and Discussion}

Actual TCSA increased gradually over the years (Fig. 1A). Canopy volume increased gradually between the fourth year and seventh after planting. Afterwards, it decreased (Fig. 1B). This decrease in canopy volume is likely a result of the effect of the high yield in the previous years (See Fig. 3A). In an intensive apple orchard with M.9 rootstock, canopy volume of trees must be compatible with tree spacing and a decrease in the annual canopy volume between the years six and eight after planting is crucial to keep trees within their allotted space. Thus, in the location of this experiment, often growers having an intensive apple orchard on highly fertile soils are facing an unbalanced tree canopy with too many long extension shoots,
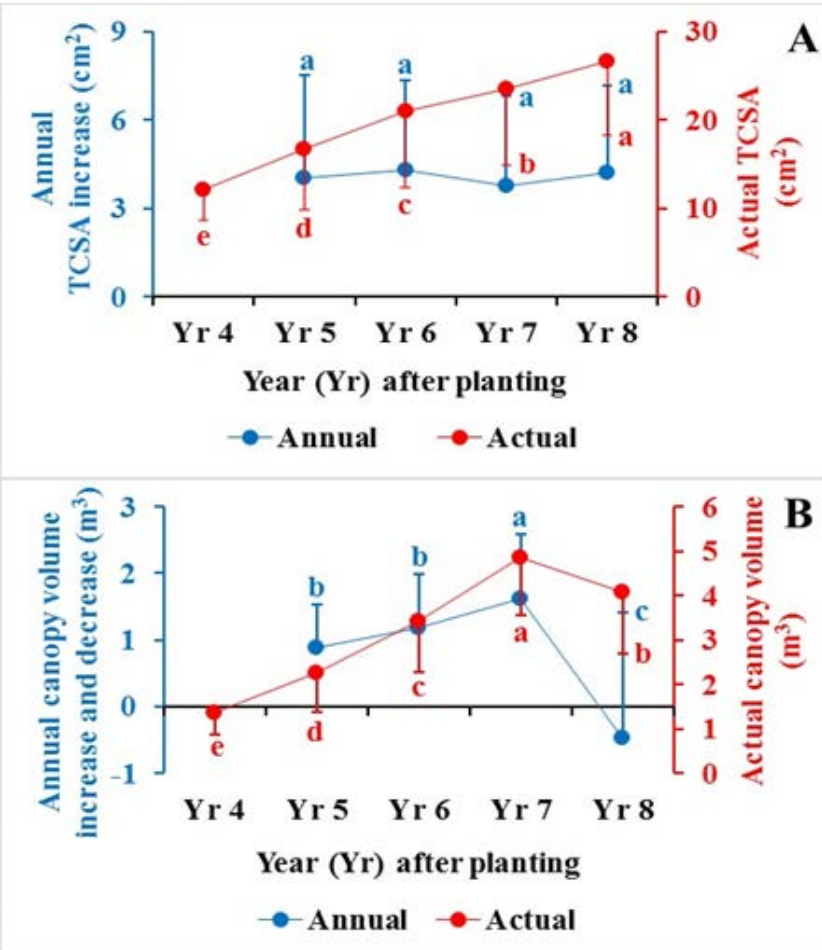

Fig. 1. Trunk cross-sectional area (TCSA) and canopy volume values of 'Golden Delicious' / M.9 trees trained to Vertical Axis system, from the fifth to the eighth year after planting (A) annual TCSA increase, and actual TCSA $(n=96)$, and (B) annual canopy volume increase and decrease, and actual canopy volume $(n=96)$. Different letters indicate statistical difference between years at $P<0.05$. The values shown are means \pm standard deviation (sd) 
234

Table 1. Pairwise correlations between shoot length and other variables studied of 'Golden Delicious'/M.9 trees trained to Vertical Axis system in the seventh and eighth year after planting

\begin{tabular}{|c|c|c|}
\hline Variable & By variable & Correlation \\
\hline Annual TCSA increase $\left(\mathrm{cm}^{2}\right)$ & Shoot length $(\mathrm{cm})$ & $-0.82^{*}$ \\
\hline Actual TCSA $\left(\mathrm{cm}^{2}\right)$ & Shoot length $(\mathrm{cm})$ & $-0.31^{*}$ \\
\hline Annual canopy volume increase and decrease $\left(\mathrm{m}^{3}\right)$ & Shoot length $(\mathrm{cm})$ & $0.73^{*}$ \\
\hline Actual canopy volume $\left(\mathrm{m}^{3}\right)$ & Shoot length $(\mathrm{cm})$ & 0.25 \\
\hline Yield $\left(\mathrm{kg} \mathrm{tre} \mathrm{t}^{-1}\right)$ & Shoot length $(\mathrm{cm})$ & $0.71^{*}$ \\
\hline $\mathrm{YE}_{\mathrm{TCSA}}$ & Shoot length $(\mathrm{cm})$ & $0.79^{*}$ \\
\hline $\mathrm{YE}_{\mathrm{TCSAInc}}$ & Shoot length $(\mathrm{cm})$ & $0.71^{*}$ \\
\hline $\mathrm{YEVol}_{\mathrm{o}}$ & Shoot length $(\mathrm{cm})$ & $0.69^{*}$ \\
\hline Soluble solids content (SSC) (\%) & Shoot length $(\mathrm{cm})$ & $-0.82^{*}$ \\
\hline Fruit flesh firmness $\left(\mathrm{kg} \mathrm{cm}^{-2}\right)$ & Shoot length $(\mathrm{cm})$ & 0.21 \\
\hline Titratable acidity $(\%)$ & Shoot length $(\mathrm{cm})$ & $0.47^{*}$ \\
\hline Fruit weight $(\mathrm{g})$ & Shoot length $(\mathrm{cm})$ & -0.04 \\
\hline Fruit skin colour (b* value) & Shoot length $(\mathrm{cm})$ & $-0.81^{*}$ \\
\hline $\mathrm{pH}$ & Shoot length $(\mathrm{cm})$ & $0.83^{*}$ \\
\hline
\end{tabular}

particularly in the top of a tree, in the seventh onwards. Carrying out similar cultural practices such as pruning and fertilization each year without considering the yield of trees may reveal this type of negative situations.

Shoot length was longer in the seventh year than in the eighth year after planting (Fig. 2). Most of the variables studied correlated significantly with shoot length (Table 1). The yield, $\mathrm{YE}_{\mathrm{TCSA}}, \mathrm{YE}_{\mathrm{Vol}}$ and annual canopy volume increase and decrease showed a positive correlation to shoot length. TCSA (annual increase and actual) correlated negatively with shoot length. Shoot growth in spring (i.e. spring flush) is preformed in the winter buds, i.e. dependent on reserves stored in the tree (Sabatier and Barthelemy, 2001; Lauri, 2007). Although bourse shoots are neoformed vegetative growth units developed as sylleptic axillary shoots generated from the axils of preformed spur leaves (Costes and Guedon, 2002), results in the current study suggest that the growth potential of bourse shoots might be established in the previous year (as in the other shoots). In this experiment, heading cuts back to old wood were not used on the scaffold branches studied, and a successive flush of growth (i.e. summer flush) did not occur. In this case, it can be put forward that there is no negative subsequent-year effect of low yield ('off-year') on vegetative growth at shoot level on trees if no pruning takes place. Early data of Lauri $e t a l$. (2010) suggest that high yield interacts with secondary (cambial) growth later in the season (when primary growth is ceased), especially on old tree portions, and, eventually, reduces secondary growth. Thus, according to the 'coordination theory', in which there is a linear correlation between shoot growth and root growth, primary growth (shoot length here) is not affected by yield, and competition mainly is of fruit and roots, decreasing the vegetative growth at whole-tree level (Genard et al., 2008; Lauri et al., 2010). In contrast, a high yield (in the 'on-year') may not cause a reduction in vegetative growth at shoot level. However it is not a common strategy, keeping the trees with no pruning may be more favorable in the 'off-year' of biennial cycle of fruiting. This strategy may prevent the generation of long reaction shoots in the subsequent-year ('off-year'), leading to an imbalance between vegetative growth at shoot level and fruiting. Thus, severe heading cuts have been shown to stimulate vegetative growth at shoot level while decreasing trunk and root growth (Mika et al., 2003; Atay and Koyuncu, 2013; Atay and Koyuncu, 2016).

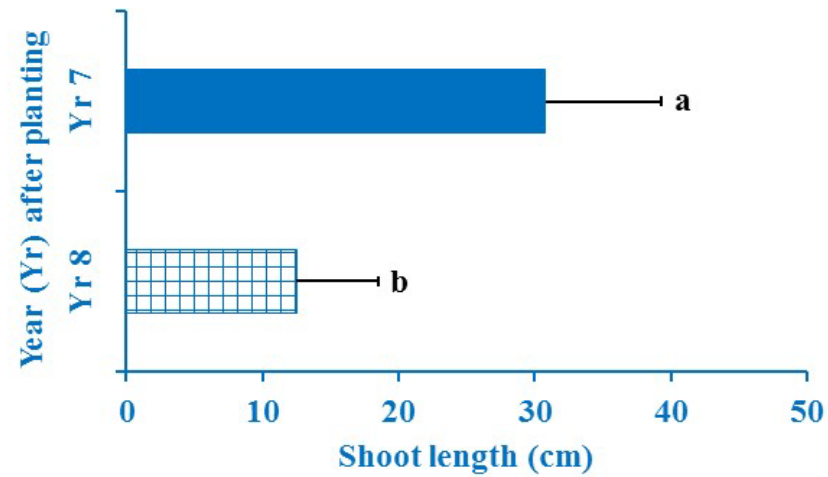

Fig. 2. Shoot length values of 'Golden Delicious'/M.9 trees trained to Vertical Axis system in the seventh and eighth years after planting $(n=96)$. Different letters indicate statistical difference between years at $P<0.05$. The values shown are means $\pm \mathrm{sd}$

Titratable acidity and $\mathrm{pH}$ correlated positively with shoot length, while SSC, fruit weight and fruit skin colour were negatively correlated (Table 1). During the cell division stage which determines final fruit quality, developing shoots have priority for limited nutrients over the fruit (Quinlan and Preston, 1971; Breen et al., 2015). In the current experiment, relatively low SSC, fruit weight and fruit skin colour values, accompanied by longer shoots, appeared to be associated with yield (See Fig. 3A). High yield penalizes fruit quality especially SSC, size and skin colour (Robinson et al., 2009; Atay, 2016; Serra et al., 2016).

The value for $\mathrm{BBI}$ was determined as $0.62 \pm 0.23$ that meant yield varied biennially (Fig. 3A). The degree of biennial bearing characterized by a year of high yield ('on-year') is followed by a year of no fruit, or low yield ('off-year') varies with cultivar (Chan and Cain, 1967; Monselise and Goldschmidt, 1982). 'Golden Delicious', the plant material of this study, has been found susceptible to biennial bearing in the local conditions of the study (Atay et al., 2013). By diminishing competition between flower initiation and fruit formation, fruit growers can diminish the adverse effects of high yield on next year's flowering (Guitton et al., 2012; Smith and Samach, 2013). However, in the current experiment, neither blossom thinning 

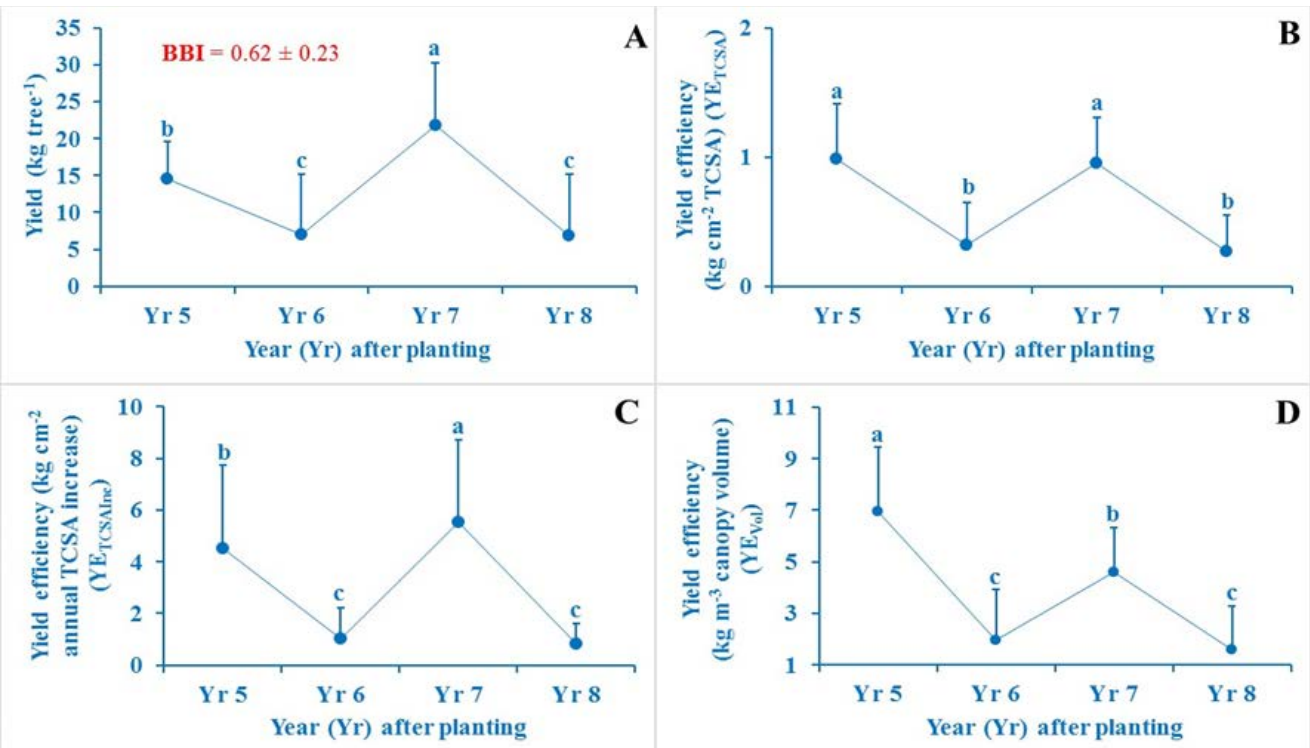

Fig. 3. Yield and yield efficiency values of 'Golden Delicious'/M.9 trees trained to Vertical Axis system, from the fifth to the

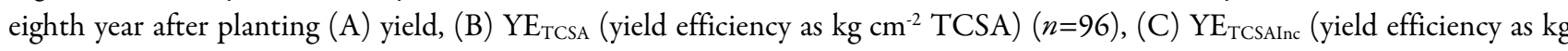

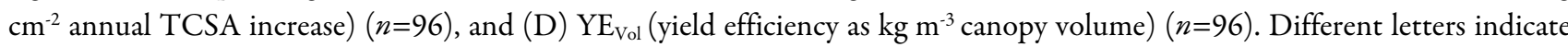
statistical difference between years at $P<0.05$. The values shown are means \pm standard deviation (sd). BBI: Biennial bearing index
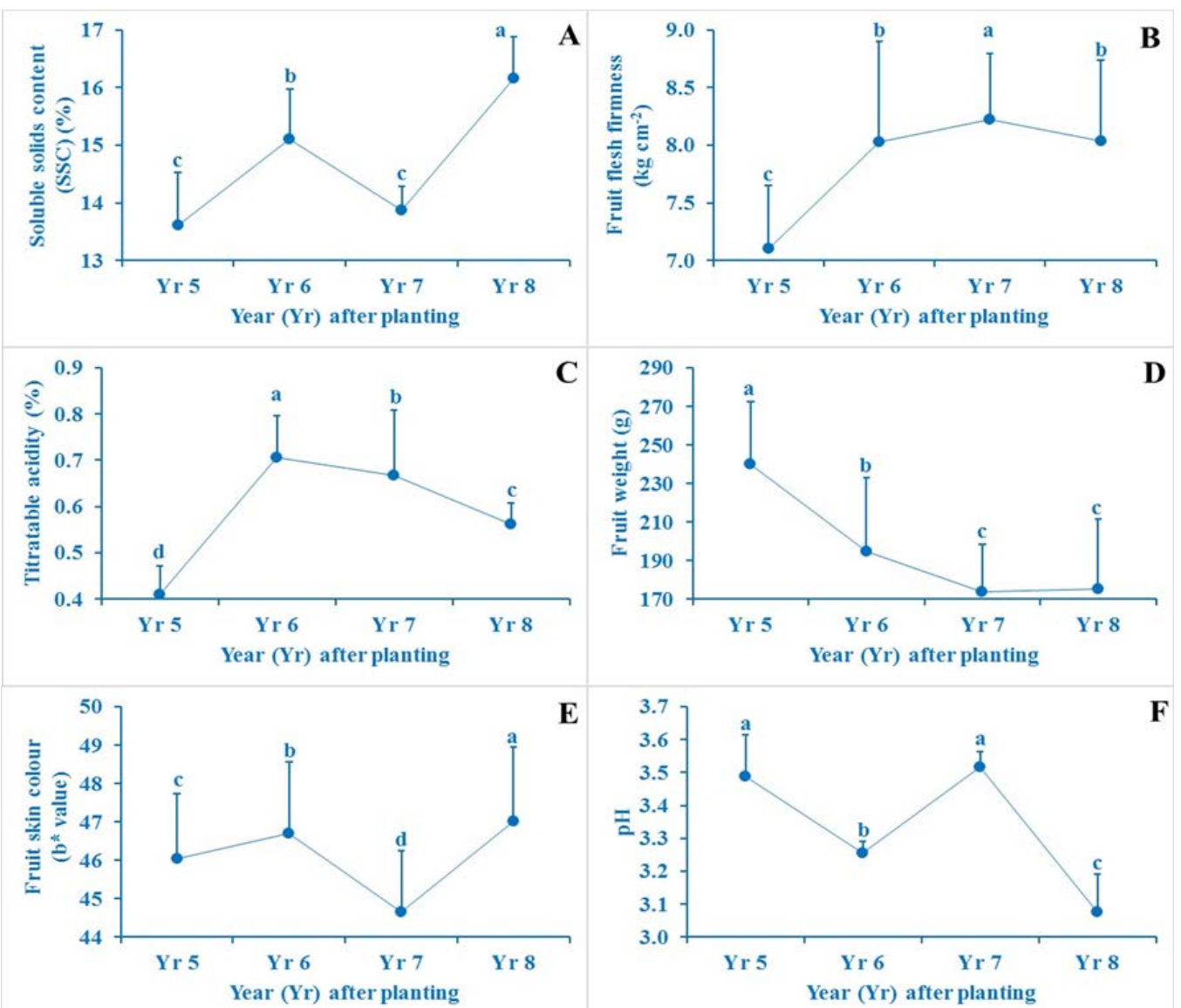

Fig. 4. Fruit quality characteristics of 'Golden Delicious'/M.9 trees trained to Vertical Axis system, from the fifth to the eighth year after planting (A) soluble solids content $(n=24)$, (B) fruit flesh firmness $(n=240)$, (C) titratable acidity $(n=24)$, (D) fruit weight $(n=240)$, (E) fruit skin colour ( $\mathrm{b}^{*}$ value) $(n=240)$, and $(\mathrm{F}) \mathrm{pH}(n=24)$. Different letters indicate statistical difference between years at $P<0.05$. The values shown are means \pm sd 
236

Table 2. Correlation among vegetative growth, yield and fruit quality characteristics of 'Golden Delicious' /M.9 trees trained to Vertical Axis system, from the fifth to the eighth year after planting

\begin{tabular}{|c|c|c|c|c|c|c|c|c|c|c|c|c|c|c|}
\hline Variable & $\mathrm{v} 1$ & v2 & $\mathrm{v} 3$ & $\mathrm{v} 4$ & v5 & $\mathrm{v} 6$ & v7 & $\mathrm{v} 8$ & v9 & $\mathrm{v} 10$ & v11 & $\mathrm{v} 12$ & v13 & v14 \\
\hline Ann.TCSA $_{\text {Inc }}(\mathrm{v} 1)$ & 1.00 & $0.52^{*}$ & $-0.79^{*}$ & $0.33^{*}$ & $-0.24^{*}$ & $-0.42^{*}$ & $-0.44^{*}$ & $-0.40^{*}$ & $0.65^{*}$ & 0.20 & -0.09 & $-0.36^{*}$ & $0.43^{*}$ & $-0.66^{*}$ \\
\hline Actual TCSA (v2) & & 1.00 & $-0.24^{*}$ & $0.83^{*}$ & $0.23^{*}$ & $-0.31^{*}$ & -0.15 & $-0.36^{*}$ & $0.31^{*}$ & $0.37^{*}$ & $0.25^{*}$ & $-0.45^{*}$ & 0.13 & $-0.28^{*}$ \\
\hline Ann.Can.Vol.IncDec (v3) & & & 1.00 & 0.01 & $0.45^{*}$ & $0.46^{*}$ & $0.42^{*}$ & $0.36^{*}$ & $-0.54^{*}$ & -0.02 & $0.22^{*}$ & 0.14 & $-0.49^{*}$ & $0.68^{*}$ \\
\hline Actual Can.Vol. (v4) & & & & 1.00 & $0.46^{*}$ & -0.06 & 0.05 & $-0.28^{*}$ & 0.14 & $0.52^{*}$ & $0.35^{*}$ & $-0.57^{*}$ & $-0.23^{*}$ & -0.06 \\
\hline Yield (v5) & & & & & 1.00 & $0.81^{*}$ & $0.61^{*}$ & $0.66^{*}$ & $-0.46^{*}$ & -0.02 & 0.01 & -0.01 & $-0.62^{*}$ & $0.54^{*}$ \\
\hline $\mathrm{YE}_{\mathrm{TCSA}}(\mathrm{v} 6)$ & & & & & & 1.00 & $0.65^{*}$ & $0.91^{*}$ & $-0.58^{*}$ & $-0.32^{*}$ & $-0.26^{*}$ & $0.30^{*}$ & $-0.63^{*}$ & $0.66^{*}$ \\
\hline YE $_{\text {TCSAInc }}(\mathrm{v} 7)$ & & & & & & & 1.00 & $0.58^{*}$ & $-0.63^{*}$ & $-0.20^{*}$ & -0.13 & $0.23^{*}$ & $-0.61^{*}$ & $0.67^{*}$ \\
\hline $\mathrm{YE}_{\mathrm{Vol}}(\mathrm{v} 8)$ & & & & & & & & 1.00 & $-0.58^{*}$ & $-0.56^{*}$ & $-0.42^{*}$ & $0.52^{*}$ & $-0.42^{*}$ & $0.60^{*}$ \\
\hline SSC (v9) & & & & & & & & & 1.00 & $0.39^{*}$ & $0.31^{*}$ & $-0.32^{*}$ & $0.52^{*}$ & $-0.72^{*}$ \\
\hline Firmness (v10) & & & & & & & & & & 1.00 & $0.60^{*}$ & $-0.75^{*}$ & -0.05 & $-0.29^{*}$ \\
\hline Acidity (v11) & & & & & & & & & & & 1.00 & $-0.43^{*}$ & -0.04 & -0.18 \\
\hline F. weight (v12) & & & & & & & & & & & & 1.00 & 0.12 & $0.32^{*}$ \\
\hline Colour $\left(b^{*}\right)(v 13)$ & & & & & & & & & & & & & 1.00 & $-0.54^{*}$ \\
\hline $\mathrm{pH}(\mathrm{v} 14)$ & & & & & & & & & & & & & & 1.00 \\
\hline
\end{tabular}

${ }^{*}$ Correlation significant at $P<0.05$. vl: annual TCSA (trunk cross-sectional area) increase $\left(\mathrm{cm}^{2}\right)$; v2: actual TCSA ( $\left.\mathrm{cm}^{2}\right)$; v3: annual canopy volume increase and decrease $\left(\mathrm{m}^{3}\right)$; $\mathrm{v} 4$ : actual canopy volume $\left(\mathrm{m}^{3}\right)$; v5: yield $\left(\mathrm{kg}_{\text {tree }}{ }^{-1}\right)$; 6 : YETCSA: yield efficiency $\left(\mathrm{kg} \mathrm{cm}^{-2} \mathrm{TCSA}\right)$; v7: YETCSAInc: yield efficiency $\left(\mathrm{kg} \mathrm{cm}{ }^{-2}\right.$ annual TCSA increase); v8: YEvol: yield efficiency ( $\mathrm{kg} \mathrm{m}^{-3}$ canopy volume); v9: soluble solids content (SSC) (\%); v10: fruit flesh firmness ( $\left.\mathrm{kg} \mathrm{cm}^{-2}\right)$; v11: titratable acidity (\%); v12: fruit weight (g); v13: fruit skin colour (b* value); $v 14: \mathrm{pH}$

nor artificial extinction (Lauri et al., 1995; Tustin et al., 2012; Atay and Lauri, 2013) carried out, and fruit thinning by hand was applied after the physiological drop. At this stage of fruit development (i.e. after physiological drop), thinning has no or little effect on biennial bearing because flower initiation is already established (Westwood, 1993). When yield was the highest $\left(21.76 \pm 8.46 \mathrm{~kg}\right.$ tree $\left.{ }^{-1}\right)$ (i.e. in the seventh year after planting) (Fig. 3A), annual TCSA increase was relatively low $\left(3.75 \pm 3.06 \mathrm{~cm}^{2}\right)$ (see Fig. 1A). A tree with low or no yield has a relatively high vegetative growth at whole-tree level (Smith and Samach, 2013). There were significant year-to-year fluctuations in $\mathrm{YE}_{\mathrm{TCSA}}$ (Fig. 3B), $\mathrm{YE}_{\mathrm{TCSAnc}}$ (Fig. 3C) and $\mathrm{YE}_{\mathrm{Vol}}$ (Fig. 3D).

The values for SSC $(13.61 \pm 0.92 \%)$ (Fig. 4A), fruit flesh firmness $(7.13 \pm 0.61 \mathrm{~kg})$ (Fig. $4 \mathrm{~B})$ and titratable acidity $(0.41 \pm 0.06 \%)$ (Fig. 4C) were lower in the fifth year after planting with the highest fruit weight value $(240.08 \pm 32.54 \mathrm{~g})$

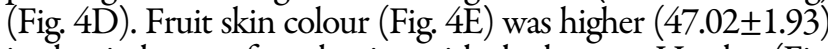
in the sixth year after planting with the lowest $\mathrm{pH}$ value (Fig. 4F) $(3.08 \pm 0.11)$. These results for fruit quality may be bound up with the yield. Thus, SSC, fruit flesh firmness, titratable acidity and skin colour negatively, fruit weight and $\mathrm{pH}$ positively correlated with yield efficiency (Table 2). A high yield affects SSC and skin colour value negatively due to a shortage of carbohydrate supply for fruit (Robinson et al., 2009; Atay et al., 2010; Atay, 2016; Serra et al., 2016). A relatively high $\mathrm{pH}$ value in the fruit was observed in the high cropping years which can be attributed to delayed fruit ripening. High yield ('on-year') extends maturity (Wünsche and Ferguson, 2004). Fruit weight correlated negatively with fruit flesh firmness. Unexpectedly, the positive correlation between fruit weight and yield efficiency can be postulated to an extreme fruit weight value in the fifth year after planting.

\section{Conclusions}

This study showed that vegetative growth at shoot level reacted differently to yield than the vegetative growth at the whole-tree level, here quantified by TCSA and canopy volume. The biennially variation of yield was within an acceptable tonnage ( 55-65 tha $\left.{ }^{-1}\right)$ for the experimental area of Bogazova Valley of Egirdir, Isparta, Turkey in the seventh year after planting. The yield affected fruit quality. Orchard management practices (e.g. pruning fruit load adjustments and nitrogenbased fertilization) between the years six and eight after planting should be conducted with caution to maintain the equilibrium between the vegetative and the reproductive functions in the tree. This study supported the idea that cultural practices such as pruning should not be conducted without considering the actual yield. To maintain orchard management effectively, keeping the trees with no pruning or light pruning is recommended in the 'off-year' of biennial bearing cycle.

\section{Acknowledgements}

The author thanks Dr. Pierre-Eric Lauri (INRA, Montpellier, France) and Dr. Christopher B. Watkins (Cornell University, New York, USA) for their fruitful comments on the paper.

\section{References}

Alcobendas R, Miras-Avalos JM, Alarcon JJ, Pedrero F, Nicolas E (2012). Combined effects of irrigation, crop load and fruit position on size, color and firmness of fruits in an extra-early cultivar of peach. Scientia Horticulturae 142:128-135.

Atay E, Pirlak L, Atay A (2010). Determination of fruit growth in some apple varieties. Tarmm Bilimleri Dergisi - Journal of Argicultural Sciences 16:1-8.

Atay E, Lauri PE (2013). Meyve agaclarinda yeni bir uygulama: Merkezkac terbiye sistemi [A new practice in fruit trees: Centrifugal training system]. Derim - Journal of Bati Akdeniz Agricultural Research Institute 30(1):65-75 (in Turkish).

Atay AN, Koyuncu F, Atay E (2013). Relative susceptibility of selected apple cultivars to alternate bearing. Journal of Biological and Environmental Sciences 7:81-86.

Atay E, Koyuncu F (2013). A new approach for augmenting branching of nursery trees and its comparison with other methods. Scientia Horticulturae 160:345-350.

Atay E, Koyuncu F (2016). Branch induction via prolepsis in apple nursery trees. Acta Horticulturae 1139:439-444. 
Atay E (2016). Which nutrients in the leaf decrease linearly as fruit load increases in apples? A preliminary study. 1. International Academic Research Congress. Antalya, Turkey pp 656-659.

Breen KC, Tustin DS, Palmer JW, Close DC (2015). Method of manipulating floral bud density affects fruit set responses in apple. ScientiaHorticulturae 197:244-253.

Chan B, Cain J (1967). The effect of seed formation on subsequent flowering in apple. Journal of the American Society for Horticultural Science 91:63-67.

Costes E, Guedon Y (2002). Modelling branching patterns on 1-year-old trunks of six apple cultivars. Annals of Botany 89:513-524.

Genard M, Dauzat J, Franck N, Lescourret F, Moitrier N, Vaast P, Vercambre $G$ (2008). Carbon allocation in fruit trees: from theory to modelling. Trees 22(3):269-282.

Guitton B, Kelner JJ, Velasco R, Gardiner SE, Chagne D, Costes E (2012). Genetic control of biennial bearing in apple. Journal of Experimental Botany 63:131-149.

Hoblyn TN, Grubb NH, Painter AC, Wates BL (1936). Studies on biennial bearing-I. Journal of Pomology and Horticultural Science 14:39-76.

JMP Development Group (2007). JMP Statistics and Graphics Guide, Version 7.0 (SAS Institute, Cary, NC).

Lauri PE, Terouanne E, Lespinasse JM, Regnard JL, Kelner JJ (1995). Genotypic differences in the axillary bud growth and fruiting pattern of apple fruiting branches over several years-an approach to regulation of fruit bearing. Scientia Horticulturae 64:265-281.

Lauri PE, Lespinasse JM (2000). The vertical axis and solaxe systems in France. Acta Horticulturae 513:287-296.

Lauri PE (2007). Differentiation and growth traits associated with acrotony in the apple tree (Malus $\times$ domestica, Rosaceae). American Journal of Botany 94(8):1273-1281.

Lauri PE, Kelner JJ, Trottier C, Costes E (2010). Insights into secondary growth in perennial plants: its unequal spatial and temporal dynamics in the apple (Malus domestica) is driven by architectural position and fruit load. Annals of Botany 102:607-616.

Lauri PE, Corelli-Grappadelli L (2014). Tree architecture, flowering and fruiting - thoughts on training, pruning and ecophysiology. Acta Horticulturae 1058:291-298.

Mika A, Buler Z, Krawiec A (2003). Effects of various methods of pruning apple trees after planting. Journal of Fruit and Ornamental Plant Research 11:33-43.
Monselise SP, Goldschmidt EE (1982). Alternate bearing in fruit trees. Horticultural Reviews4:128-173.

Pearce SC, Dobersek-Urbanc S (1967). The measurement of irregularity in growth and cropping. Journal of Horticultural Science 42(3):295-305.

Pellerin BP, Buszard D, Georgallas A, Nowakowski RJ (2012). A novel framework to consider endogenous hormonal control of apple tree flowering. HortScience 47:589-592.

Quinlan JD, Preston AP (1971). The influence of shoot competition on fruit retention and cropping of apple trees. Journal of Horticultural Science 46(4):525-534.

Robinson T (2003). Apple-orchard planting systems. In: Ferree DC, Warrington IJ (Eds). Apples: botany, production and uses. CABI Publishing, Cambridgepp 345-407.

Robinson T, Lopez S, Lungerman K, Reginato G (2009). Crop load management for consistent production of Honeycrisp apples. New York Fruit Quarterly 17:24-28.

Sabatier S, Barthelemy D (2001). Bud structure in relation to shoot morphology and position on the vegetative annual shoots of Juglans regia L. (Juglandaceae). Annals of Botany 87(1):117-123.

Serra S, Leisso R, Giordani L, Kalcsits L, Musacchi S (2016). Crop load influences fruit quality, nutritional balance, and return bloom in 'Honeycrisp' apple. HortScience 51(3):236-244.

Smith HM, Samach A (2013). Constraints to obtaining consistent annual yields in perennial tree crops. I: Heavy fruit load dominates over vegetative growth. Plant Science 207:158-167.

Tustin DS, Dayatilake GA, Breen KC, Oliver MJ (2012). Fruit set responses to changes in floral bud load - A new concept for crop load regulation. ActaHorticulturae 932:195-202.

Westwood MN (1993). Temperate-zone pomology: physiology and culture (ThirdEdition). Timber Press, Oregon.

Wünsche JN, Ferguson IB (2004). Crop load interactions in apple. In: Janick J (Ed). Horticultural Reviews 31. John Wiley and Sons Inc, Oxford, UK pp 231-290.

Zhao D, Yuan J, Xu K, Cheng C, Li H (2016). Selection of morphological, physiological and biochemical indices: evaluating dwarfing apple interstocks in cold climate zones. New Zealand Journal of Crop and Horticultural Science 44(4):291-311. 